\section{Aprender Sobre... Educar Para... O Uso Sustentável Da Água: Uma Proposta Metodológica De Ensino Com Base No Uso Da Água No Passado}

\author{
Learning About... Educating for.... The \\ Sustainable Use of Water: A Methodological \\ Proposal for Teaching Based on the Use of \\ Water in the Past
}

\section{Helena Margarida Tomás}

Instituto Politécnico de Castelo Branco

Castelo Branco, Portugal

helenatomas@ipcb.pt

(iD) 0000-0002-5349-3393

\section{Margarida Afonso}

Instituto Politécnico de Castelo Branco

Castelo Branco, Portugal

margarida.afonso@ipcb.pt

(iD) 0000-0002-1858-1275

\section{Marta Marques}

Universidade de Southampton

Southampton, Reino Unido

marta.sofia.97@hotmail.com

iD 0000-0002-4498-8044

\section{Información del artículo: \\ Recibido: 18 marzo 2020 \\ Revisado: 6 noviembre 2020 \\ Aceptado: 15 diciembre 2020}

$\begin{array}{ll}\text { ISSN } & 2340-8472 \\ \text { ISSNe } & 2340-7743 \\ \text { DOI } & 10.17561 / \text { AT.18.5365 }\end{array}$

(c) $\mathrm{CC}-\mathrm{BY}$

(C) Universidad de Jaén (España). Seminario Permanente Agua, Territorio y Medio Ambiente (CSIC)

\section{RESUM 0}

Apresenta-se uma proposta metodológica de ensino com vista a uma maior consciencialização, por parte das crianças e dos jovens, para problemas relacionados com a água que afetam o planeta e a sua sustentabilidade; a proposta visa, assim, contribuir para uma maior e melhor educação para a água. Na proposta dá-se particular relevância a tradições que se relacionam com o transporte e armazenamento da água, permitindo o desenvolvimento de conhecimentos científicos e de competências e a valorização das tradições, dos saberes ancestrais. Embora as tradições abordadas sejam particularmente portuguesas, dão-se exemplos de outros países e, simultaneamente, exploram-se os objetivos do desenvolvimento sustentável (ODS), particularmente os ODS 4 - Educação de qualidade - e 6 - Água e saneamento. A proposta de intervenção apela também ao envolvimento dos contextos educativos não formais, como por exemplo o Clube UNESCO Ciência, Tradição e Cultura, de forma a complementar aprendizagens desenvolvidas nos contextos educativos formais.

PALAVRAS-CHAVE: Água; Educação formal, Educação não formal, Sustentabilidade; Objetivos do desenvolvimento sustentável.

\section{ABSTRACT}

The paper is a teaching methodological proposal so children and young people have a better consciousness of waterrelated issues that affect the planet and its sustainability; i.e. it aims to contribute to a wider and better education about water. Relevance is given to the traditions, particularly the ones related to the transport and storage of water, allowing the development of scientific knowledge and skills, and valuing cultural and ancestral traditions and knowledge. Although the mentioned traditions are mostly Portuguese, examples from other countries are also given; simultaneously, the Sustainable Development Goals (SDG), particularly SDG 4 - quality education - and SDG 6 - water and sanitation - are explored. This intervention proposal is also an appeal to involving non-formal educational contexts, such as the UNESCO Club Science, Tradition and Culture, to complement the knowledge acquired in formal educational contexts - schools. 
Aprender sobre... educar para... el uso

sostenible del agua: una propuesta

metodológica para la enseñanza basada en el uso del agua en el pasado

\section{RESUMEN}

Se presenta una propuesta metodológica de enseñanza con el objetivo de crear conciencia, por parte de niños y jóvenes, sobre los problemas relacionados con el agua que afectan el planeta y su sostenibilidad; en otras palabras, la propuesta apunta a contribuir a una mejor educación para el agua. Si da especial importancia a las tradiciones relacionadas con el transporte y almacenamiento de agua, permitiendo el desarrollo de conocimientos y habilidades científicas, así como la mejoría de conocimientos culturales/ancestrales. Aunque las tradiciones cubiertas sean particularmente portuguesas se dan ejemplos de otros países y se exploran los Objetivos del Desarrollo Sostenible (ODS), particularmente el ODS 4 - Educación de calidad - y el ODS 6 - Agua y saneamiento. La propuesta de intervención también pide la participación de contextos educativos no formales, como el Club de Ciencia, Tradición y Cultura de la UNESCO, para complementar el aprendizaje desarrollado en contextos educativos formales.

PALABRAS CLAVE: Agua, Educación formal, Educación no formal,

Sostenibilidad, Objetivos de desarrollo sostenible.

Apprendre sur... éduquer à... I'utilisation durable de l'eau : une proposition méthodologique d'enseignement fondée sur l'utilisation de l'eau dans le passé

\section{RÉSUMÉ}

Nous présentons une proposition méthodologique d'enseignement en vue de sensibiliser les enfants et les jeunes à des problèmes liés à l'eau qui affectent la planète et sa durabilité ; cette proposition vise ainsi à contribuer à une meilleure éducation à l'eau. Dans cette proposition, une importance particulière est accordée à des traditions liées au transport et au stockage de l'eau, permettant le développement de connaissances scientifiques et de compétences et la mise en valeur des traditions et des savoirs ancestraux. Bien que les traditions abordées soient particulièrement portugaises, des exemples d'autres pays sont donnés et, en même temps, les objectifs de développement durable (ODD) sont explorés, en particulier les ODD 4 - Éducation de qualité - et 6 - Eau et assainissement. Notre proposition d'intervention appelle également à la participation des contextes éducatifs non formels, tels que le Club de l'UNESCO Science, Tradition et Culture, afin de compléter les apprentissages développés dans les contextes éducatifs formels.

MOTS-CLÉS: Eau, Éducation formelle, Éducation non formelle, Durabilité, Objectifs de développement durable.

Imparare... educare per... I'uso sostenibile dell'acqua: una proposta metodologica di insegnamento basata sull'uso dell'acqua nel passato

\section{SOMMARIO}

Viene presentata una proposta metodologica didattica in un'ottica di sensibilizzazione, da parte di bambini e ragazzi, sui problemi legati all'acqua che incidono sul pianeta e sulla sua sostenibilità; la proposta mira quindi a contribuire a una maggiore e migliore educazione nei confronti dell'acqua. Nella proposta, particolare rilevanza è data alle tradizioni che riguardano il trasporto e lo stoccaggio dell'acqua, consentendo lo sviluppo di conoscenze e competenze scientifiche e la valorizzazione di tradizioni e saperi ancestrali. Sebbene le tradizioni trattate siano specificatamente portoghesi, vengono forniti esempi di altri paesi e, allo stesso tempo, vengono esplorati gli Obiettivi di Sviluppo Sostenibile (SDG), in particolare gli SDG 4 - Istruzione di qualità - e 6 Acqua e igiene. La proposta di intervento prevede anche il coinvolgimento di contesti educativi non formali, come il Club Scienza, Tradizione e Cultura dell'UNESCO, al fine di integrare gli apprendimenti sviluppati in contesti educativi formali.

PAROLE-CHIAVE: Acqua, Educazione formale, Educazione non formale, Sostenibilità, Obiettivi di Sviluppo Sostenibile. 
O futuro da humanidade e do nosso planeta está nas nossas mãos. Também está nas mãos da geração mais jovem de hoje, que passará a tocha para as gerações futuras. Temos mapeado o caminho para o desenvolvimento sustentável; caberá a todos nós garantir que a jornada seja bem-sucedida e que os seus ganhos sejam irreversíveis ${ }^{1}$.

\section{Introdução}

Atualmente, parece consensual que a educação é a chave para a necessária mudança de mentalidades e de atitudes da sociedade e que ela deve permitir formar cidadãos comprometidos com o presente e com o futuro. Por outro lado, é nosso entendimento que a educação é um "processo através do qual os indivíduos adquirem domínio e compreensão de certos conteúdos considerados valiosos" ${ }^{2}$ na nossa sociedade atual.

De entre estes conteúdos está a água. Segundo dados divulgados na Cimeira das Nações Unidas sobre o Desenvolvimento Sustentável, realizada em 2002 em Joanesburgo, sob a égide das Nações Unidas, estimava-se que aproximadamente $18 \%$ da população mundial não tinha acesso a água potável. Ou seja, que cerca de uma em cada seis pessoas vivia em situação de stress hídrico, não possuindo água suficiente para satisfação das suas necessidades básicas. A situação hoje é ainda mais preocupante e segundo o Relatório Mundial das Nações Unidas sobre desenvolvimento dos recursos hídricos de 2019 (WWDR 2019), intitulado "Não deixar ninguém para trás", são já três em cada dez pessoas que não têm acesso a água potável segura, sendo que "os números globais encobrem desigualdades significativas entre e dentro das regiões, dos países, das comunidades e até mesmo de bairros" 3 .

Revelam-se hoje de extrema importância os problemas relacionados não só com a sua escassez, mas também com a sua (má) qualidade e com a sua desigual distribuição não só no nosso planeta em geral, mas também no nosso país em particular. Apesar de, em 2017, 96 \% da população portuguesa estar abrangida pelas redes de água canalizada e de, em 2018, 98,6 \% dessa água ser de boa qualidade para o consumo humano ${ }^{4}$ o certo é que a falta de água e a sua má qualidade, por exemplo, em alguns rios, como o Tejo podem vir a

\footnotetext{
1. UN (United Nations), 2015, 16.

2. Chaves, 2014, 17.

3. UNESCO, 2019, 1.

4. FFMS, 2019a; 2019b.
}

afetar/afetam, de forma direta ou indireta, a vida das populações (Figura 1).

Como afirmou Quintella no II Seminário Transfronteiriço sobre o Desenvolvimento das Comunidades Ribeirinhas do rio Tejo:

"O principal problema do rio Tejo está relacionado com a falta de água. É um facto que as alterações climáticas explicam uma parte da água que acaba por não chegar a Portugal, mas também não podemos esquecer o resto: as inúmeras captações para uso doméstico, uso industrial, os próprios transvases que acontecem no troço superior do rio Tejo. [...] É preciso monitorizar. É preciso dizer exatamente qual é a quantidade de água que é precisa, não só para abastecimento público, industrial e para produzir energia, mas também para que a lampreia marinha continue a migrar ao longo do rio, para que seja possível pescar algumas das espécies que existem. E isso é possível saber"5.

Adicionalmente, também se tem vindo a assistir à diminuição das reservas hídricas disponíveis em resultado de mudanças globais e locais, dos inúmeros erros humanos e do aumento da população mundial. Esta situação assume contornos cada vez mais preocupantes que põem em causa a satisfação das necessidades de um número cada vez maior de pessoas, para além de ameaçar os ecossistemas e a sua biodiversidade ${ }^{6}$. São problemas atuais muito preocupantes que a sociedade tem de enfrentar.

São vários os estudos que têm vindo a apontar no sentido de que, devido à sua degradação e escassez, a água venha a constituir-se, num futuro muito próximo, como uma das principais preocupações da humanida$\mathrm{de}^{7}$, podendo mesmo tornar-se a origem de possíveis conflitos à escala regional, nacional e internacional. Ainda que, na antiguidade, a distribuição e o acesso à água nem sempre tenha sido pacífico, ela era vista como repleta de valores simbólicos, culturais e místicos e venerada em muitas e diferentes culturas. Contudo, hoje, a água vem sendo olhada de forma distinta; como refere Silva no seu estudo 0 curso da água na história: Simbologia, Moralidade e gestão de recursos hídricos, ela "deixou de ser símbolo e torna-se elemento de possíveis conflitos"8.

$\mathrm{Na}$ base da chamada crise contemporânea da água está a injustiça no seu acesso, pelo que no mundo glo-

\footnotetext{
5. 0 Mirante, 2018.

6. Serra, 2012, 77-78.

7. Serra, 2012, 76.

8. Silva, 1998, 11.
} 
Figura 1. Rio Tejo (Foto: Paulo Novais/Lusa).

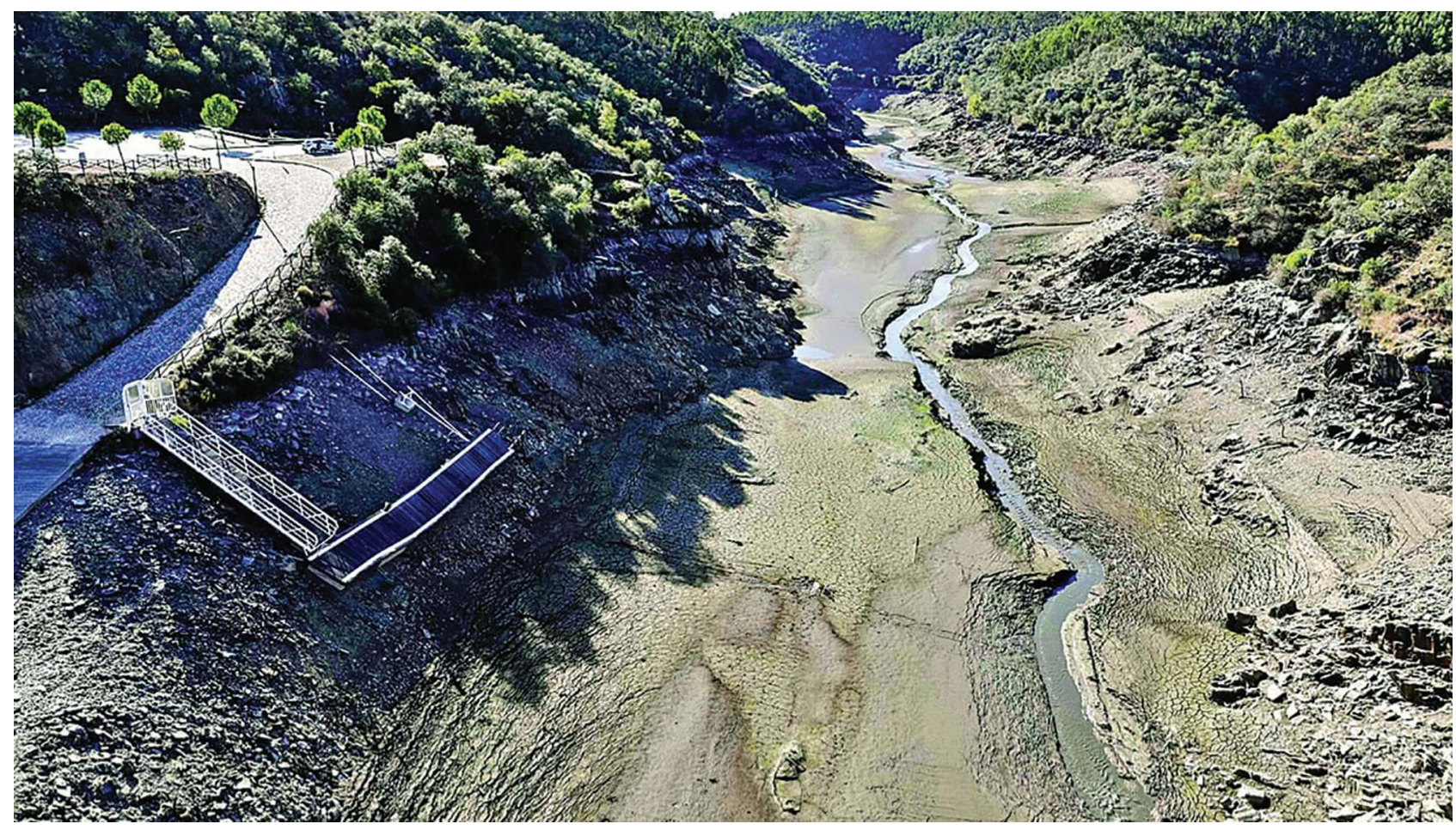

Fonte: https://www.cmjornal.pt/portugal/cidades/detalhe/espanha-deixa-rio-tejo-a-seco-e-causa-desastre-na-beira-baixa.

balizado de hoje é urgente uma educação para a água de qualidade, uma educação promotora de uma cidadania responsável que permita aos indivíduos interiorizar conhecimentos, capacidades, atitudes e valores a respeito da água. Como refere o pedagogo Freire ${ }^{9}$, não é a educação que transforma o mundo, mas é a "educação [que] transforma as pessoas. Elas transformam o mundo".

É fundamental que cada um de nós assuma a sua própria responsabilidade no que respeita à sua contribuição para a preservação dos recursos hídricos. Como já em 2006 era referido no Relatório do Desenvolvimento Humano, do Programa das Nações Unidas para o Desenvolvimento (PNUD):

\begin{abstract}
"A água está presente em todos os aspetos do desenvolvimento humano. Quando as pessoas veem negado o seu acesso à água potável no lar ou quando não têm acesso à água enquanto recurso produtivo, as suas escolhas e liberdades são limitadas pela doença, pobreza e vulnerabilidade. A água dá vida a tudo, incluindo o desenvolvimento humano e a liberdade humana"10.
\end{abstract}

O reconhecimento da água como um conteúdo valioso aparece bem presente em diversas publicações ${ }^{11}$, e apresenta-se como um compromisso do Clube UNESCO Ciên-

\footnotetext{
9. Freire, $1987,87$.

10. PNUD, 2006, 10.

11. WWF-Brasil, 2007a; 2007b.
}

cia, Tradição e Cultura (CTeC) do Instituto Politécnico de Castelo Branco. O CTeC, enquanto contexto de educação não formal, tem como finalidade contribuir para a salvaguarda da memória coletiva através da preservação das tradições e da cultura portuguesas. Neste sentido, procura dar a conhecer tradições, interpretando-as do ponto de vista científico. Para tal, faz investigação sobre as mesmas, em fontes primárias e secundárias, concetualiza materiais e recursos didáticos destinados a diferentes públicos e faz a sua divulgação através de diversas iniciativas, como sejam a publicação de livros e a realização de oficinas práticas, workshops, formação e encontros.

Os projetos desenvolvidos pelo $\mathrm{CTeC}$ fundamentam-se também nos objetivos estratégicos definidos pela Agenda 2030 para o desenvolvimento sustentável da Organização das Nações Unidas (ONU). Na proposta metodológica de ensino que aqui se apresenta o $\mathrm{CTeC}$ tem em consideração a exploração dos objetivos do desenvolvimento sustentável (ODS), em particular dos ODS 4 - Educação de qualidade - e 6 - Água e saneamento - e o reconhecimento da necessidade, desde cedo, de uma educação para a água e de uma valorização da forma como no passado se usava a água, justificam o título do presente artigo: Aprender sobre... educar para... o uso sustentável da água: uma proposta metodológica de ensino com base no uso da água no passado. Este conjunto de princípios conduziram à apresentação de uma estratégia didática 
que permite explorar não só conhecimentos científicos, mas também refletir sobre outros aspetos essenciais na compreensão da sua importância em todas as dimensões da vida e da necessidade de um planeta mais sustentável. Esta estratégia foi pilotada com crianças de várias idades - 1.ํ e 2.ำ ciclos do ensino básico (6-11 anos) -, e é a partir dessa pilotagem que se apresenta esta proposta de ação.

\section{A proposta metodológica}

\section{A água, a sustentabilidade e os objetivos de desenvolvimento sustentável - Fundamentos}

A água está no centro do desenvolvimento sustentável e das suas dimensões ambiental, social, económica e cultural, fundamentais para o bem-estar dos indivíduos e das sociedades. Desde a segunda metade do século passado que a questão da água como um direito fundamental começou a ser explorada. 0 direito à água potável segura foi reconhecido formalmente como um direito humano básico e universal pela Assembleia Geral da ONU em 2010, sendo mencionado em diversos instrumentos jurídicos como, a título de exemplo, na Resolução 15/9 do Conselho dos Direitos Humanos ${ }^{12}$ e na Resolução A/RES/64/292 da Assembleia Geral das Nações Unidas ${ }^{13}$. É, assim, imperativo que toda a população, independentemente da região ou do continente em que habita, tenha acesso a água potável. E, de acordo com as diretrizes estabelecidas pela Organização Mundial de Saúde (OMS), a água para ser apropriada ao consumo humano não pode apresentar nenhum risco significativo para a saúde ao longo da sua vida ${ }^{14}$.

Ainda que alguns autores apresentem apenas três dimensões da sustentabilidade - económica, social e ambiental -, em conformidade com o conceito de desenvolvimento sustentável formalizado pela primeira vez de forma clara em 1987 no relatório "O Nosso Futuro Comum", também conhecido como "Relatório Brundtland", considerando-as igualmente importantes, outros autores apresentam dimensões complementares e em diferente número ${ }^{15}$. Entre estas surge a dimensão cultural. Por exemplo, Catalisa ${ }^{16}$ considera sete dimensões do desenvolvimento sustentável, definindo a dimensão cultural como a dimensão relacionada com os diferentes valores entre os povos e com o estímulo a processos de mudança que acolham as especificidades locais, além da manutenção dos valores e da cultura locais, visando à preservação do património cultural. Já Werbach ${ }^{17}$ acrescenta às dimensões económica, social e ambiental a cultural, relativa à proteção e à valorização da diversidade, entendendo-a como o conjunto de ações por meio das quais as comunidades manifestam a sua identidade e transmitem tradições de geração em geração. Como Martins e Nunes advogam, a sustentabilidade cultural, quarto pilar do desenvolvimento sustentável, veio recentrar o "entendimento de que a cultura é crucial para a aplicação de políticas de sustentabilidade já que desenha o modo como encaramos os recursos naturais e sobretudo como construímos as relações com o Outro" ${ }^{18}$.

A Comissão Europeia reconhece mesmo que a qualidade de vida, em termos ambientais, é antes de mais um desafio cultural e realça o papel da comunidade e das práticas culturais na mudança estrutural. Nesta perspetiva, as práticas culturais tornam-se essenciais na sustentabilidade ambiental e no desenvolvimento sustentável pela inclusão da sustentabilidade cultural ${ }^{19}$. Atualmente, "sustentável" implica outorgar uma importância central aos fatores culturais, pelo que o verdadeiro desenvolvimento necessita de incluir, também, esses processos culturais.

Assim, no contexto da globalização, é fundamental que se preserve a identidade cultural e se fomente o diálogo intercultural. A Declaração Universal sobre a Diversidade Cultural, da Organização das Nações Unidas para a Educação, a Ciência e a Cultura (UNESCO), assinada em 2002, define cultura como "o conjunto das características espirituais e materiais, intelectuais e afetivas que caracterizam uma sociedade ou um grupo social e que abrange, além das artes e das letras, os estilos de vida, as maneiras de viver juntos, os sistemas de valores, as tradições e as crenças" ${ }^{20}$. A mesma Declaração reconhece o papel central da cultura nos debates contemporâneos sobre identidade, coesão social e desenvolvimento de uma economia baseada no conhecimento e, no seu artigo 1., sublinha que ela "constitui o património comum da humanidade, devendo ser reconhecida e afirmada em benefício das ge-

\footnotetext{
12. UN, 2010a.

13. UN, $2010 \mathrm{~b}$.

14. OMS, 2011

15. Froehlich, 2014.

16. Froehlich, 2014, 159.
} 
rações atuais e das gerações futuras" ${ }^{21}$. Por sua vez, o artigo 7.- - Património cultural, fonte de criatividade salienta que:

"Toda a criação se baseia nas tradições culturais, mas desenvolve-se plenamente em contacto com outras. É por isso que o património, em todas as suas formas, deve ser preservado, valorizado e transmitido às gerações futuras como testemunho da experiência e das aspirações humanas, a fim de alimentar a criatividade em toda a sua diversidade e estabelecer um verdadeiro diálogo entre as culturas"22.

Em 2015, a Organização das Nações Unidas (ONU), baseada e dando continuidade aos oito Objetivos de Desenvolvimento do Milénio (ODM) ${ }^{23}$, adotou o documento intitulado "Transformando o Nosso Mundo: A Agenda 2030 para o Desenvolvimento Sustentável" 24 , estabelecendo 17 Objetivos do Desenvolvimento Sustentável (ODS), num total de 169 metas associadas, que representam as prioridades e as aspirações globais a prosseguir até 2030. Estes 17 ODS vieram alterar a forma de abordar o desenvolvimento sustentável, considerando-o um desafio que diz respeito a todos, pois: integram várias dimensões do desenvolvimento sustentável; assentam em objetivos e metas universais a serem implementados por todos os países; têm uma maior dimensão de combate às desigualdades e à promoção dos Direitos Humanos, como preocupação transversal a todos os ODS; e implicam uma nova dinâmica de conjugação de esforços de uma multiplicidade de atores ${ }^{25}$.

Desses objetivos, o ODS 6 - Garantir a disponibilidade e a gestão sustentável da água potável e do saneamento para todos - foca em particular o acesso à água segura, com a meta 6.1 a explicitar expressamente a necessidade de até 2030 se alcançar o acesso universal e equitativo à água potável e segura. Ele relaciona-se com todos os outros 16 ODS, quer de forma direta, quer de forma indireta: a água é especificamente mencionada nalgumas das metas do ODS 3 - Vida saudável (metas 3.3 e 3.9), do ODS 5 - Cidades e comunidades sustentáveis (meta 11.5), do ODS 12 - Produção e consumo sustentáveis (meta 12.4) e do ODS 15 - Ecossistemas terrestres e biodiversidade (meta 15.1), estando implícita em metas de todos os outros onze ODS (Figura 2). É neste senti-

\footnotetext{
21. UNESCO, 2002, 2.

22. UNESCO, 2002, 3.

23. $\mathrm{ONU}, 2000$.

24. UN, 2015.

25. Cabaço, 2017, 5 .
}

do que no Relatório Mundial das Nações Unidas sobre o desenvolvimento dos recursos hídricos, de 2019, se diz que o ODS 6 "é considerado um desses ODS centrais, devido às suas funções vitais relacionadas com a saúde humana, a dignidade, a integridade e a prosperidade ambiental e com a própria sobrevivência do planeta" 26 .

No que respeita ao desempenho nacional em relação aos ODS, em 2019, de acordo com a informação disponibilizada pelo Instituto Nacional de Estatística ${ }^{27}$, os indicadores em que Portugal se encontrava mais próximo dos objetivos foram os relativos à eliminação da pobreza (ODS 1), da qualidade da educação (ODS 4), do trabalho digno e do crescimento económico (ODS 8) e da paz, justiça e instituições eficazes (ODS 16). Em relação ao ODS 6, concretamente à meta 6.1, a evolução, desde 2010 até 2018, último ano com informação disponível, foi favorável, embora no último ano não tenham ocorrido alterações. Portugal surge em 15. lugar entre os 28 países da União Europeia no Índice dos Objetivos do Desenvolvimento Sustentável ${ }^{28}$ (IODS), obtendo uma pontuação de 66,2 em 100, abaixo da média europeia $(70,1)$.

Dada a centralidade e a importância da água para a sustentabilidade do nosso planeta, patente na posição que assume frente a todos os outros ODS, e conscientes de que as crianças de hoje serão os adultos de amanhã, torna-se fundamental que a sua educação releve a água. É fundamental uma educação preocupada não só com a aquisição de conhecimento científico, neste caso a respeito da água, mas também que tenha em conta o seu caráter cultural e as suas implicações sociais, ambientais e económicas.

Com o desenvolvimento das atividades que leva a cabo, o CTeC constitui-se como um espaço que promove atividades que ampliam esses conhecimentos sobre a água, valorizando a cultura a ela subjacente, levando à (re)construção de atitudes mais adequadas às atuais problemáticas e ao desenvolvimento de valores mais consentâneos com uma sociedade que se pretende social, económica, ambiental e culturalmente mais sustentável. Só uma educação de qualidade permitirá consciencializar os mais novos dos problemas sociais, ambientais, económicos e culturais que a escassez e a má qualidade da água têm vindo a colocar à sociedade. Só uma educação de qualidade permitirá formar futuros cidadãos com memória e evitar que esta se perca.

\footnotetext{
26. UNESCO, 2019, 40

27. INE, 2019.

28. 0 índice foi elaborado pela Rede de Soluções para o Desenvolvimento Sustentável das Nações Unidas e pelo Instituto para a Política Ambiental Europeia com o objetivo de se avaliar o progresso dos países da União Europeia quanto às 17 metas definidas pela ONU para 2030.
} 
Figura 2. A presença da água nos objetivos do desenvolvimento sustentável.

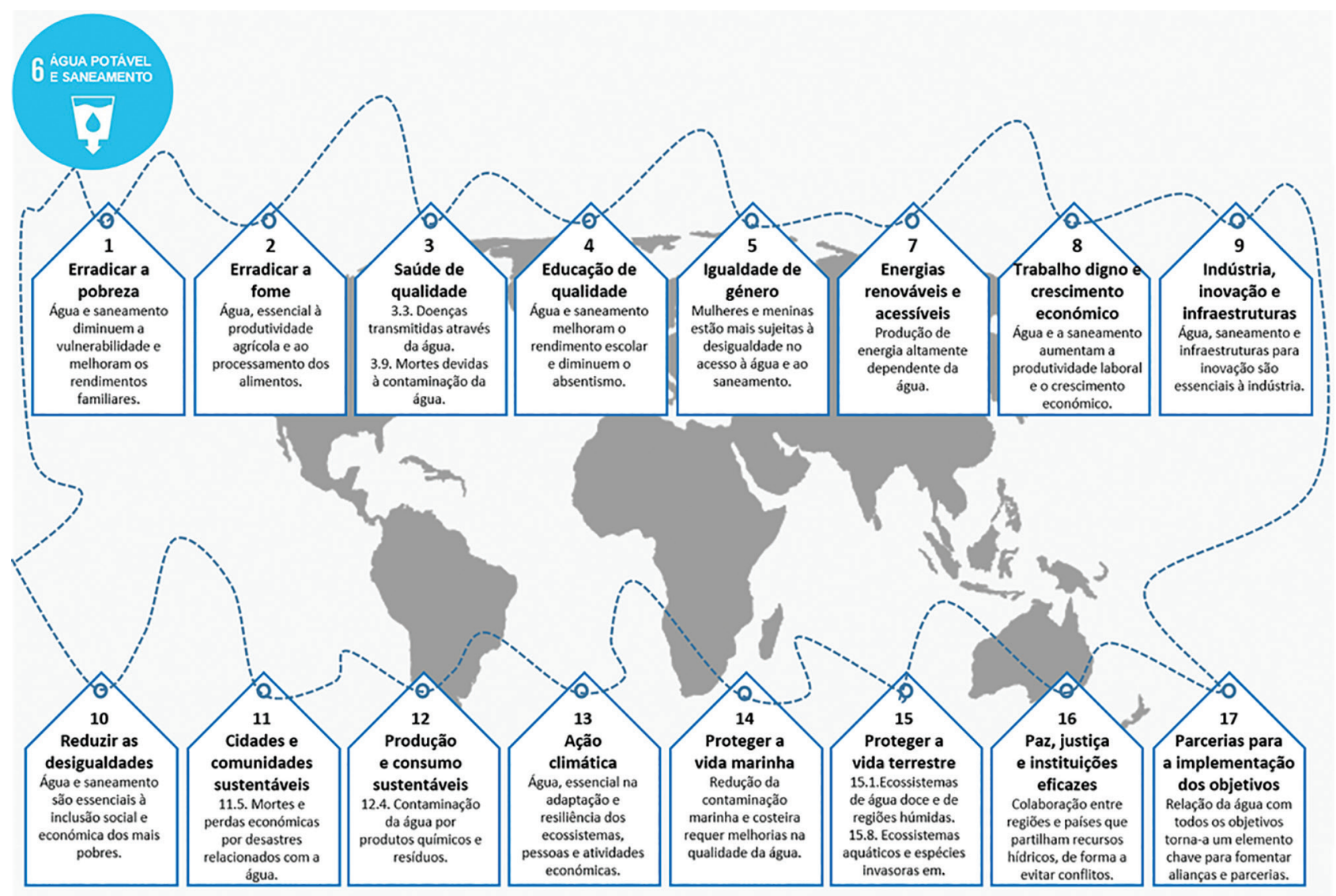

E para se almejar uma melhor educação para a água é necessário que as crianças sejam protagonistas no presente para poderem decidir o seu futuro ${ }^{29}$.

\section{A água, a escola e o Clube UNESCO Ciência, Tradição e Cultura - Relação entre contextos}

É indiscutível a importância da escola, enquanto instituição de educação formal, no processo de ensino e aprendizagem das ciências das crianças e embora também se reconheça a importância dos contextos de aprendizagem não formal na educação científica não se tem a pretensão de que substituam o ensino formal. De facto, a educação formal, escolar, pode ser: [...] complementada ou acrescida de uma educação não-formal e informal, extra-escolar, que tem de certa forma oferecido à sociedade o que a escola não pode oferecer ${ }^{30}$.

\footnotetext{
29. Comissão da Cultura - Cidades e Governos Locais Unidos, 2015.

30. Gaspar, 1993, 1-2.
}

Como referem vários autores ${ }^{31}$, a articulação funcional entre os contextos formais e não formais pode incrementar a educação científica das crianças, contribuindo para o seu maior envolvimento, motivação e cooperação, para a melhoria da qualidade das suas aprendizagens e para a valorização do seu potencial enquanto futuros cidadãos mais pró-ativos numa sociedade em mudança.

Contudo, a discussão sobre a classificação dos tipos de educação ainda não encontrou consenso no seio dos investigadores ${ }^{32}$, apesar da terminologia formal/ não formal/informal, de origem anglo-saxónica, já ter sido introduzida na década de 60 do século passado. Neste artigo não cabe debruçar-nos sobre as conceções apresentadas pelos diversos autores, no entanto defendemos, tal como Arantes (2008) ${ }^{33}$, que se olhe para os diferentes tipos de educação não de forma estanque mas como parte de um continuum que vai da educação

\footnotetext{
31. Erich, 2018. Oliveira e Gastal, 2009.

32. Langhi e Nardi, 2009. Marandino, 2017. Marques e Freitas, 2017; 2018.

33. Citado por Oliveira e Gastal, 2009. Rogers, 2004; 2014. Marandino, 2008;
} 2017. 
formal à informal, passando pela educação não formal, na qual incluímos a educação promovida pelo $\mathrm{CTeC}$ (Figura 3).

$\mathrm{O} \mathrm{CTeC}$, enquanto contexto de educação não formal, não tem, assim, como objetivo sobrepor-se à escola. 0 seu objetivo é antes o de complementar as aprendizagens das crianças, oferecendo-lhes, de certa forma, o que a escola não lhes pode, ou não consegue, oferecer.É neste sentido que desenvolve as suas abordagens assentes numa perspetiva de complementaridade, no pressuposto de que as crianças realizam aprendizagens a partir de distintas fontes, por uma diversidade de razões e de diversas maneiras.

No que se refere em particular à água, é certo que a escola proporciona aos alunos algum conhecimento científico, e até mesmo compreensão e sensibilidade para alguns aspetos particulares acerca da atual problemática sobre a água. Contudo, frequentemente, nessa abordagem falta contextualização e abrangência, falta aproximar de forma mais evidente os conteúdos da realidade ambiental, social, económica, cultural.

Adicionalmente, o manual escolar ao afirmar-se "dentro do cenário de ensino-aprendizagem, mais como protagonista do processo do que propriamente como auxiliar" ${ }^{34}$, acaba por condicionar o que e a forma como os professores ensinam, constituindo-se como "um forte dispositivo de desautorização intelectual, cultural e profissional do sujeito docente" ${ }^{35}$. A utilização do manual escolar, muito generalizada nas escolas portuguesas ${ }^{36}$, enquanto guia da atividade letiva e elemento central do trabalho desenvolvido em sala de aula pelos professores, inclusive os do 1. ciclo do ensino básico, também tem contribuído, na nossa opinião, para que a escola não "olhe" para os aspetos relativos à água de forma integrada e contextualizada. Por exemplo, preservar a água resume-se a fechar a torneira enquanto se lavam os dentes, se toma um duche, ou a ter cuidado com as descargas do autoclismo? Motivar para este tipo de aspetos é relevante e os alunos até podem mudar os seus comportamentos, mas será que, só por si, levam à verdadeira compreensão da sua importância em prol da defesa do meio ambiente e das gerações presentes e futuras? Será que é promovida uma verdadeira tomada de consciência relativamente à água enquanto bem essencial para a humanidade e para a vida na terra? Será que é promovido o desenvolvimento de atitudes e valores imprescindíveis para viver em conjunto com os outros e para a necessária sustentabilidade do planeta?

\footnotetext{
34. Guimarães, 2009, 3.

35. Bonafé, 2011, 69.

36. Carvalho, 2015. Figueiroa, 2003. Martins, 2011.
}

É importante que os educadores percecionem a ciência como uma atividade humana, e não simplesmente como uma atividade neutra e distante dos problemas sociais ${ }^{37}$. É necessário ressignificar o tema água ${ }^{38}$, é necessário um novo olhar para o que tradicionalmente é feito nas escolas de forma a desenvolver novos sentidos, novas conexões, novas estratégias; enfim, potenciar aprendizagens mais significativas para as crianças, com vista à promoção de uma adequada literacia científica. A educação deve ser direcionada para a valorização das crianças enquanto cidadãos que definirão o futuro do planeta, contribuindo para as consciencializar do seu papel na construção de um planeta mais saudável e mais sustentável. E para tal a educação não formal desempenha um papel muito importante.

Na procura de uma maior, mas, sobretudo, melhor compreensão sobre a água e o seu impacto cultural, social, económico e ambiental, o CTeC propõe-se desenvolver atividades práticas, muitas delas experimentais, tendo por base tradições e saberes culturais sobre a água que podem ser encontradas nas várias regiões de Portugal. Defende-se que a educação e a cultura são complementares ${ }^{39}$. São estas tradições e estes saberes que podem fornecer o contexto para a exploração das atividades com as crianças permitindo, deste modo, que aprendam/relembrem não só conhecimentos científicos, mas também que têm muito a enriquecer com a valorização do passado. Este tipo de atividades que se propõem, ao mesmo tempo que contribuem para a preservação dos saberes tradicionais, culturais, permitem consciencializar de que se pode aprender muito com eles, contribuindo para a promoção de uma cidadania responsável. 0 mesmo é dizer que o seu desenvolvimento permite, concomitantemente, desenvolver uma educação de qualidade (foco do ODS 4).

Como é referido no documento Cultura 21: Ações:

"O património cultural, na multiplicidade das suas dimensões, desde a memória até à paisagem, constitui o testemunho da criatividade humana, sendo um recurso para a identidade das pessoas e dos povos. É algo vivo e em constante evolução, que deve ser integrado de maneira dinâmica na vida em sociedade.

A apropriação da informação e a sua transformação em conhecimento partilhado constitui um ato cultural interrelacionado com direito à educação, ao longo de toda a vida, e com o direito de participar na vida cultural ${ }^{, 40}$.

\footnotetext{
37. Santos, 2007.

38. Morhy, Terán e Fonseca, 2019.

39. Duarte, Werneck e Cardoso, 2013.

40. Comissão da Cultura - Cidades e Governos Locais Unidos, 2015.
} 
Figura 3. Contextos educacionais.

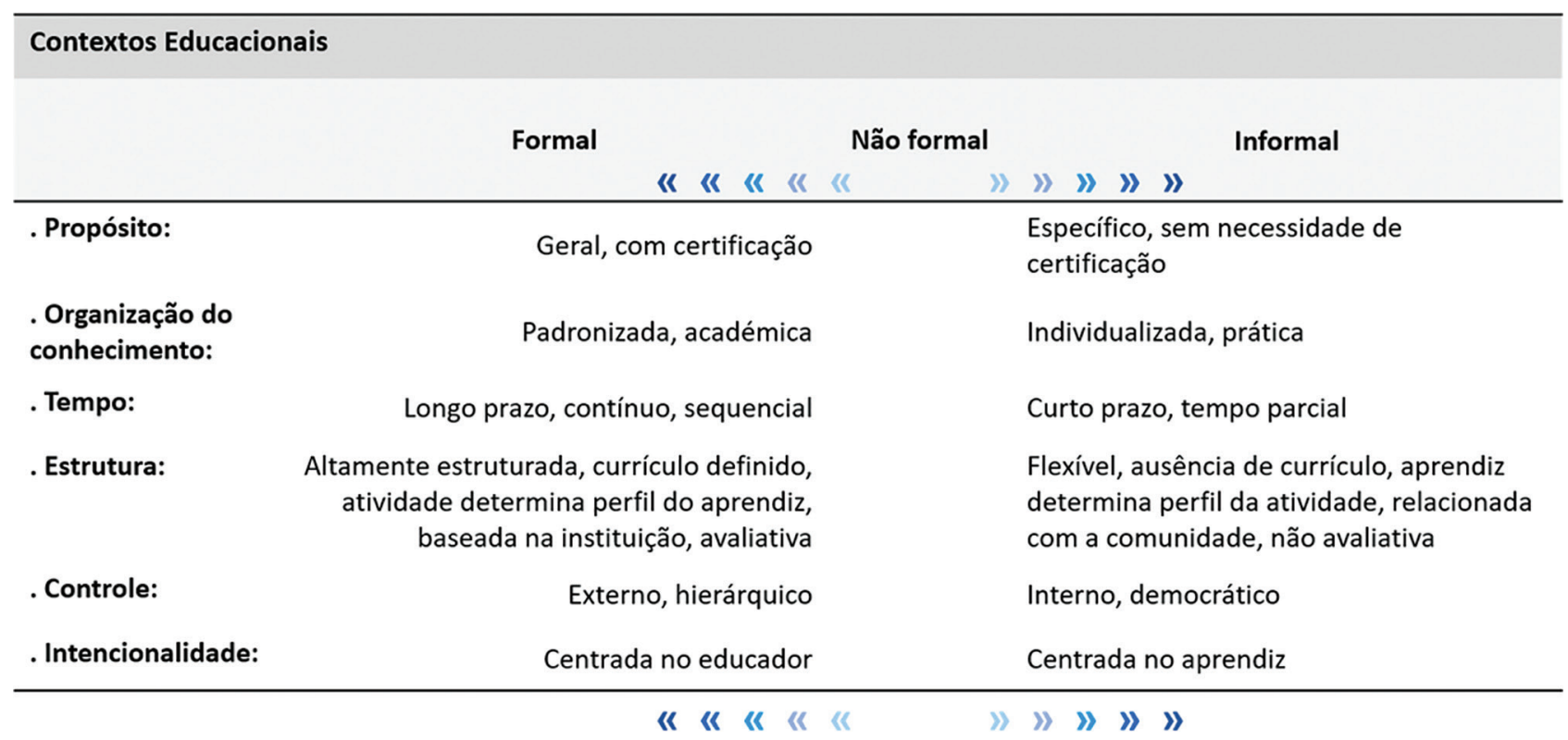

Fonte: Marandino, 2008 (adaptado)

É neste sentido que consideramos que as tradições, incluindo as relativas à água, não podem ser vistas como algo do antigamente, dos tempos idos, e sem valor. Elas são uma forma de reinterpretação desse passado, uma forma de fazer renascer esse passado em direção ao futuro. Através delas as crianças conhecem aspetos do seu passado, observam esses aspetos e preservam-nos no presente, o que contribui para que os possam projetar no futuro.

As diferentes abordagens da escola e que se propõe serem conduzidas pelo $\mathrm{CTeC}$ a respeito da água, são apresentadas na Figura 4. A intervenção educativa da escola centra-se, de uma forma geral, numa abordagem mais teórica, de conhecimentos científicos factuais a respeito da disponibilidade e da distribuição da água no planeta, do ciclo da água na natureza, das propriedades da água, do seu ciclo urbano e da sua importância para a saúde e para a vida no planeta, enquanto a intervenção educativa do CTeC procurará, através da realização de atividades práticas, muitas delas experimentais, alicerçadas em tradições e saberes culturais acerca da água, ir mais além e complementar a educação científica que a escola promoveu. A sua estratégia passará por valorizar as tradições como uma forma de promover a compreensão de boas práticas para um uso adequado da água na sociedade.

Embora não descurando os conhecimentos científicos, a ação do CTeC deverá estar centrada no desenvolvimento das capacidades de mobilização desses conhecimentos por parte das crianças, mas também de atitudes e de valores que lhes permitam compreender a água enquanto bem essencial, enquanto direito humano universal, enquanto fonte de bem-estar, enquanto bem fundamental essencial ao desenvolvimento sustentável da sociedade. Defende-se uma metodologia que através de atividades práticas, do debate e da reflexão conjunta com vista à resolução de problemas, à análise de situações concretas, promove a mobilização de conhecimentos científicos ao mesmo tempo que potencia aprendizagens de diferentes áreas disciplinares. Tal metodologia permitirá às crianças consolidar os seus conhecimentos anteriores e construir novos conhecimentos, bem como competências cognitivas, comunicacionais e sociais.

\section{Tradições ligadas à água - Os cântaros de barro}

Com a proposta metodológica de ensino que se apresenta em continuação, pretende-se que as crianças possam investigar uma tradição relacionada com a vida diária portuguesa, num tempo em que não havia água canalizada ou o abastecimento de água potável não cobria todo o território, e a possam interpretar do ponto de vista científico. Esta atividade ${ }^{41}$, alicerçada no armazenamento e no transporte da água potável em recipientes de barro não vidrado, permitirá levar as crianças a dialogar com o passado no presente, alicerce fundamental da cultura. Mas permitirá, também, estabelecer

41. Péres, Tomás e Afonso, 2015. 
Figura 4. Relação entre os contextos formal e não formal - a propósito da água.

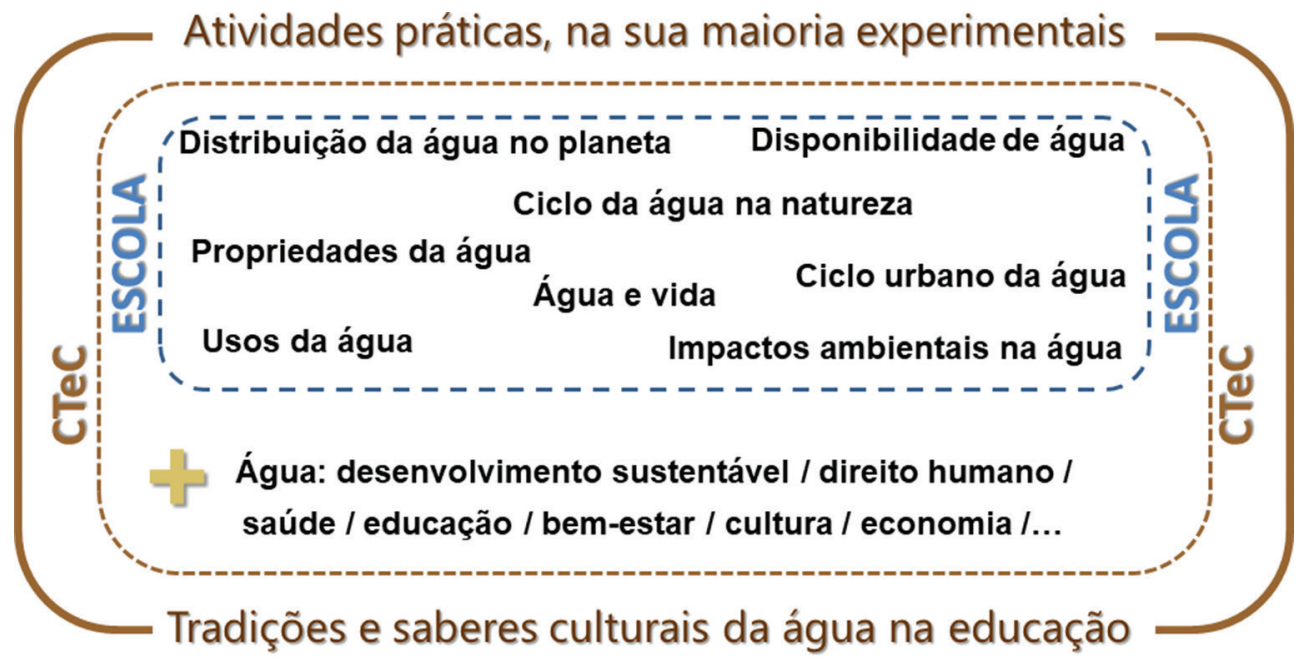

um diálogo intercultural na medida em que se trata de um modo de vida igualmente característico de outros povos e que, portanto, também traduz as suas culturas.

Nesse tempo, nas casas portuguesas era habitual haver um poial de pedra ou um móvel (banca ou banco) com um ou mais recipientes de barro não vidrado onde se colocava a água para beber que se mantinha fresca, mesmo nos dias mais quentes:

\begin{abstract}
"Dantes, todas as casas tinham na cozinha, um poial dos cântaros, onde os tamanhos mais correntes eram "a terceira" (15 litros) e a quarta (10 litros) [...] Nos poiais, lá estavam gravados muitas vezes, a cruz e o signo-saimão, símbolos mágicos de proteção contra o mau-olhado e o quebranto. Estes símbolos podiam aparecer igualmente gravados nos cântaros ou nas suas tampas de cortiça. Para além dos cântaros, existiam ainda recipientes para água de menores dimensões, como as bilhas, os moringues, as garrafas de água, os barris e os púcaros" ${ }^{\text {,42 }}$.
\end{abstract}

Alguns desses recipientes, conhecidos por talhas (Figura 5), mas cuja designação também varia consoante a região (por exemplo, em Toulões, distrito de Castelo Branco, eram conhecidas por asados), tinham frequentemente a tapá-las um pequeno prato de barro onde se colocava um copo, também de barro, protegido por um pano geralmente de linho. E para que mantivessem a água fresca, eram frequentemente areados com palha ou areia para que os seus poros se mantivessem desobstruídos.

Também o transporte da água das fontes para as habitações era realizado em cântaros de barro não vi-

\footnotetext{
42. Matos, 2012.
}

drado transportados por mulheres ou por homens, em burro, ou a pé, neste caso carregando habitualmente dois ou quatro cântaros em cada ida à fonte.

As crianças podem ser desafiadas a pensar por que se usavam, antigamente, recipientes - cantarinhas, bilhas ou cântaros - de barro não vidrado para guardar a água. Com recurso, por exemplo, a um cartão como o que se mostra abaixo, que apresenta no rosto a questão problema e no verso as etapas que elas devem seguir (Figura 6), as crianças podem envolver-se na procura da resposta ao saber fazer de outrora, fazendo previsões, manipulando e controlando variáveis, registando e interpretando resultados.

Esta atividade permitirá às crianças comprovar que o barro não vidrado mantém a água a uma temperatura inferior à temperatura ambiente, contrariamente ao que se passa quando o recipiente usado é vidrado. As crianças compreenderão que quando o recipiente não vidrado contém água, esta ocupa os poros do barro atravessando lentamente a parede do recipiente até à superfície externa e, por isso, a superfície adquire uma tonalidade mais escura. É também por esse motivo que, quando tocam na parede do recipiente, a sentem húmida. A evaporação da água dos poros na superfície exterior, retira gradualmente energia à água que está no seu interior, baixando a sua temperatura. Este processo torna-se visível às crianças pelo abaixamento do nível da água no recipiente. Por sua vez, no recipiente vidrado as crianças poderão verificar que isso não acontece, pois o vidrado obstrói os poros impedindo que a água atinja a superfície exterior e, como tal, a possibilidade de ela se evaporar.

Nesta atividade que se propõe, as alterações na cor do barro, a sensação real da superfície estar mais húmida e a diminuição do nível de água no recipiente de barro 
Figura 5. Recipientes de barro não vidrado.

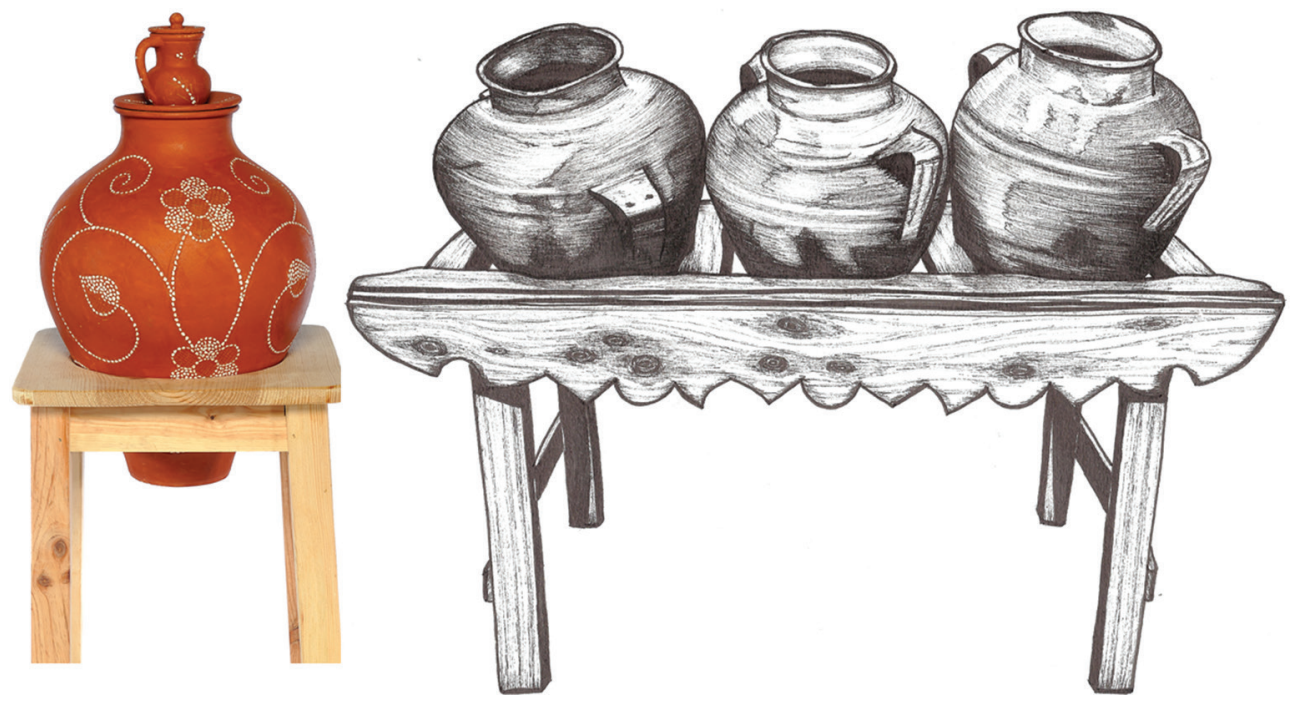

Fonte: Péres, Tomás e Afonso, 2015.

Figura 6. Cartão da atividade prática experimental.

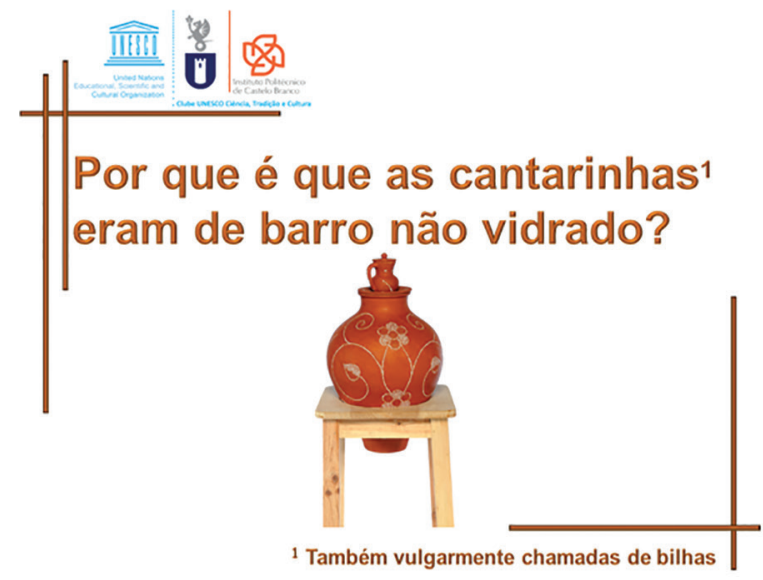

Enche com o mesmo volume de água 2 bilhas de barro, uma vidrada e outra não vidrada. Marca o nivel da água e mede a temperatura.

Tapa as bilhas. Prevê o que vai acontecer à temperatura e ao nivel da água, ao longo do tempo, em cada bilha.

Mede a temperatura de 3 Observa a superficie exterior das bilhas e
em 3 min durante $20 \mathrm{~min}$. o nivel da água ao fim de $20 \mathrm{~min}$.

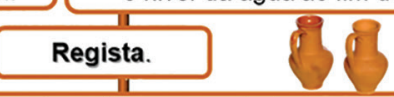

Mergulha numa tina com água duas peças de barro: uma vidrada $e$ outra não vidrada. Observa o que acontece na superfície das peças.

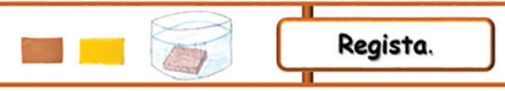

Relaciona a variação da temperatura da água nas 2 bilhas com a alteração do aspeto da superficie e do nivel da água ao longo do tempo e com o que ocorre à superfície das 2 peças mergulhadas em água.

Fonte: Péres, Tomás e Afonso, 2015.

(dados qualitativos) permitirão às crianças relacionar a porosidade do barro com a diminuição da temperatura (dados quantitativos). Há, assim, uma articulação de vários aspetos que o $\mathrm{CTeC}$ poderá acompanhar aquando da realização da atividade no sentido de ajudar as crianças a construírem conhecimentos científicos e culturais sobre a água. As crianças compreenderão, assim, que num tempo em que as famílias ainda não tinham frigorífico, lhes era possível conservar a água mais fresca recorrendo a recipientes produzidos a partir de um material poroso. Mas, concomitantemente, podem também ser levadas a compreender e a valorizar o que representou no nosso país a chegada da água canalizada às casas, o que representa hoje, para todos nós, podermos simplesmente abrir a torneira sem necessidade de irmos à fonte e transpor- tarmos a água para nossas casas. A concretização desta atividade, contextualizada numa tradição portuguesa, permitirá a apreensão do conhecimento científico de forma integrada e com significado.

Em continuação, propõe-se, através do que ocorre na cantarinha de barro não vidrado, que as crianças sejam levadas a estabelecer uma analogia com o que se passa no seu corpo quando transpiram, o que permitirá abordar a importância da água na saúde dos seres vivos, nomeadamente, no homem: quando a temperatura corporal aumenta, as glândulas sudoríparas libertam o suor, que chega à superfície da pele pelos seus poros. Em contacto com o ar, a água do suor evapora, o que faz diminuir a temperatura da superfície da pele mantendo o corpo mais fresco e dando uma sensação de frescura. 
Esta analogia poderá também ajudar as crianças a perceber qual a razão de, antigamente, se dizer que "o barro transpira" e, consequentemente, aperceberem-se de que muitos dos ditos populares dos mais velhos frequentemente resultavam do seu conhecimento empírico e que muitos são passíveis de serem explicados pela ciência. A exploração destas expressões populares, de lendas e de pregões, a título de exemplo, é muito importante já que se tratam de referências genuínas, expressão verdadeira da nossa identidade cultural, que muitas vezes, possibilitam conhecer aspetos relacionados com os modos de vida e com os usos das populações.

A atividade prática experimental, a ser implementada, permitirá também recuperar e explorar com as crianças uma antiga profissão de âmbito nacional, mas também de outros países como é o caso do México ${ }^{43}$ : o ofício de aguadeiro. O Novo Diccionario da Lingua Portugueza (1849) define aguadeiros, em português, como "o que tem officio de acarretar agua para serviço das casas, e a venda pelas ruas" ${ }^{44}$. Ou seja, os aguadeiros eram homens que, em tempos idos, ajudavam as pessoas a obter água distribuindo-a ou vendendo-a, muitas vezes de porta em porta, e que a transportavam, a pé ou no seu burro, frequentemente em bilhas de barro (Figuras $7,8$ e 9$)$.

A abordagem desta profissão com as crianças permitirá também recuperar pregões ${ }^{45}$ utilizados pelos aguadeiros para chamarem a atenção das gentes para a água que transportavam e, assim, mais uma vez, contribuir para o seu conhecimento e para a sua preservação. Os pregões, geralmente curtos, eram apregoados pelos aguadeiros com determinadas entoações e musicalidade pelas ruelas das povoações. Como Júlio de Castilho ${ }^{46}$ refere em Pregões de Lisboa, Música do Coração do Povo, "A melopeia dos pregões é música, deliciosa música, nativa no coração do povo" ${ }^{47}$. Infelizmente, são raros os registos das vozes, do tom e dos sons desses pregões, mas alguns dos idosos que ainda os recordam são capazes de os entoar. Dois destes pregões, ouvidos em Lisboa até à segunda metade do século passado, são "Áá-Áá! - Áúúú!”, “Á-ú! - Áááuga!”48. Já de Caneças, uma localidade próxima de Lisboa, onde

\footnotetext{
43. Sánchez-Rodríguez, 2017, 22-33.

44. Coelho, 2018, 191.

45. Um pregão é um anúncio proferido em voz alta.

46. Júlio de Castilho (1840-1919) foi um reputado jornalista, poeta, escritor e político português, sendo considerado o fundador da moderna olisipografia.

47. Castilho, 1968, 73.

48. "Aú", abreviação da palavra galega auga, dado que uma grande quantidade
} dos aguadeiros de Lisboa vinha da Galiza. Coelho, 2018. abundavam fontes com água de elevada qualidade, vem o pregão "Água fresca, água de Caneças". Outros exemplos de pregões, estes oriundos da região alentejana ${ }^{49}$ são: “Á-gua-dê-ro!", “Á-gua fres-qui-nha!”, “A tos-tão a bar-ri-gada!", "S’tá aqui o home da água!", "É um céu aberto a água da Fonte Nova!", e "A água da Fonte Nova percorre as veias de toda a criatura!". Outros, ainda, ouviam-se também com frequência noutras regiões do país, como: "Água fresquinha, quem quer água fresquinha", "Há água fresquinha! Quem quer quem quer?" e "Água fresquinha e pura, Olha o púcaro de água fresca". Muitos destes pregões remetem para a temperatura da água transportada e/ou para a sua potabilidade. Com a chegada da água canalizada a Portugal e o alargamento da rede pública de distribuição de água a todo o país, presenciou-se o desaparecimento da profissão e dos pregões, que são hoje raridades etnográficas em rápida extinção, mas que é importante divulgar junto dos mais novos de forma a que as possam conhecer e, assim, valorizar e preservar a nossa herança cultural.

Exemplo de outra atividade pertinente para integrar o conjunto de atividades que constituem esta proposta metodológica relativamente à problemática da água, o cerne deste artigo, assenta na possibilidade de as crianças poderem experienciar o transporte de água à cabeça, utilizando, tal como era feito antigamente, as rodilhas que são, elas próprias, também consideradas elementos do património cultural português. Trata-se de pequenas rodelas almofadadas, abertas ao centro, feitas de tiras de tecido entrançadas que eram utilizadas para carregar à cabeça os cântaros de barro (e outros recipientes) (Figura 10).

Após a experimentação do transporte da água à cabeça, da apresentação e exploração de um ditado popular associado a esta tarefa (por exemplo, "Quem não pode com o pote, não pega na rodilha" ou "Aonde se quebrou o pote, aí procura a rodilha", a atividade pode ser continuada com a exploração do excerto:

Passemos agora à corrida de cântaros. Recordo o dia 9 de Março de 1980, em que na aldeia de Constantim, próxima de Vila Real, saiu vencedora uma mulher de outra aldeia - o Couto. No fim da corrida, perguntei a uma rapariga de Constantim, com ares desembaraçados, se ela não se envergonhava por o prémio ter ido parar ao Couto. "Pudera! Aqui em Constantim há água canalizada e as mulheres não treinam a ir à fonte. Agora no Couto...".

\footnotetext{
49. Gama, 1954
} 
Figura 7. Aguadeiro. Carroça de aguadeiro no início do séc. XX (Foto de: António Crisógono dos Santos, coleção do Museu Municipal de Lagos).

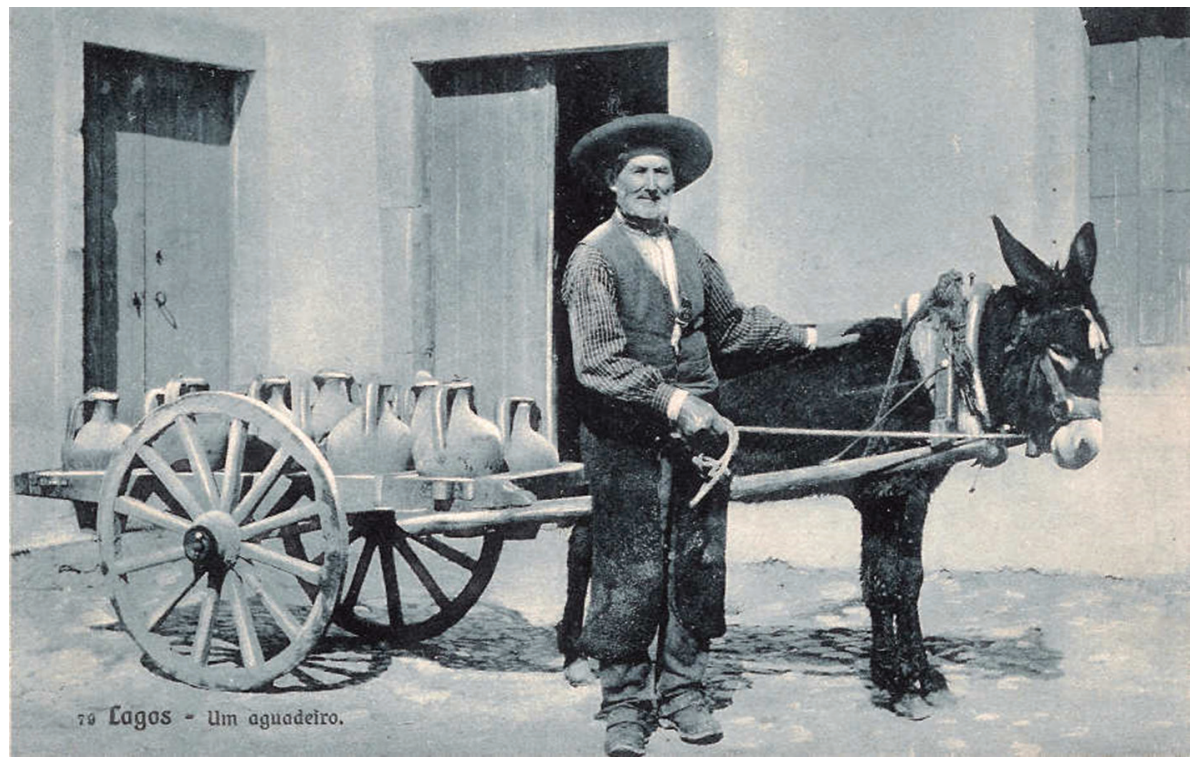

Fonte: http://delagos.pt/fototeca/index.php/Antigas/Ant-nio-Cris-gono-dos-Santos/79-Aguadeiro.

Figura 8. Burro de aguadeiro. Transportando água (Foto de: Autor desconhecido, coleção do Museu Municipal de Lagos).

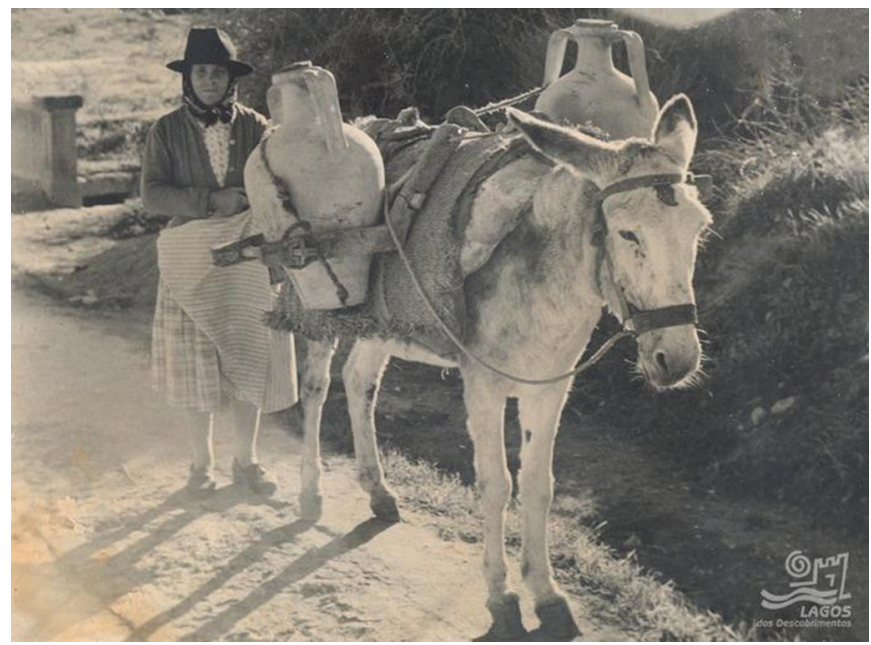

Fonte: http://delagos.pt/fototeca/index.php/Antigas/burrode-aguadeiro.

Figura 9. Aguadeira da ceifa. Capa do n. ${ }^{0} 21$, de janeiro de 1949 , da revista "menina e moça", editada pela Mocidade Portuguesa Feminina.

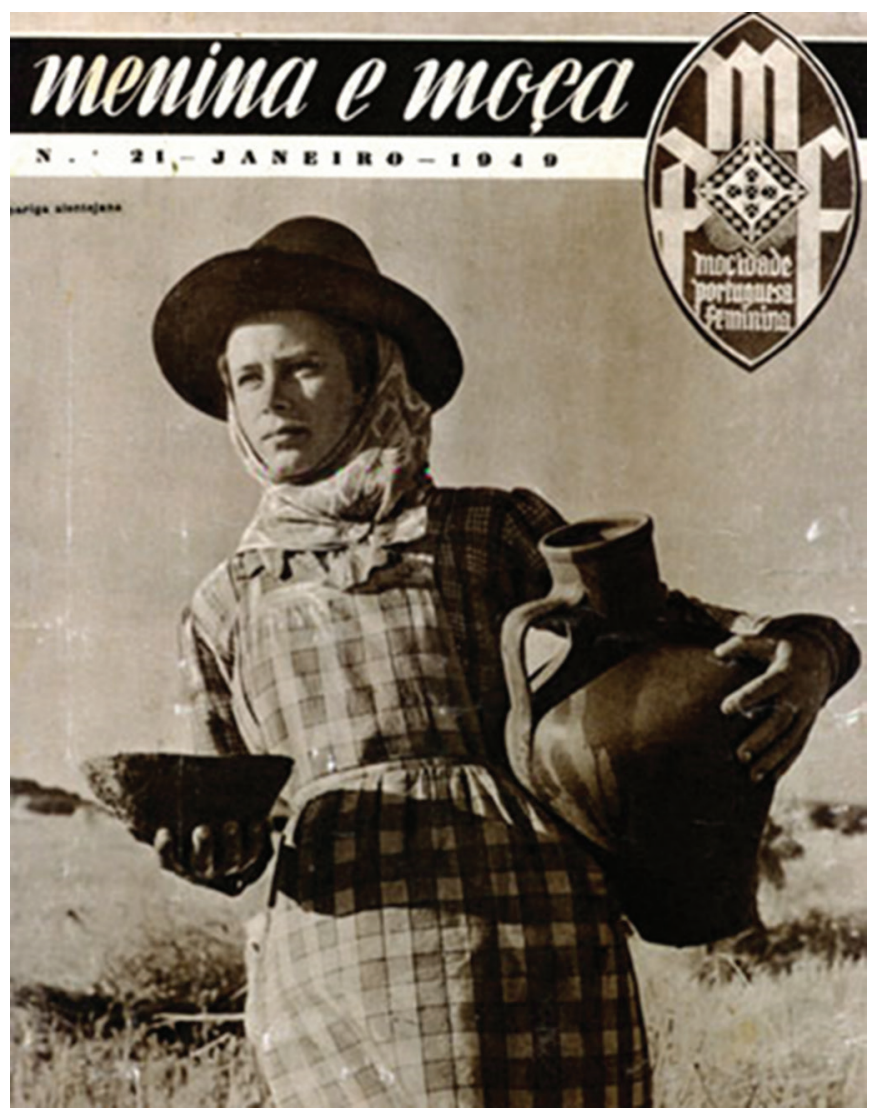

Fonte: http://omelhoralentejodomundo.blogspot.com/2013/07/relembrando-o-passado-aguadeiras.html. 
Figura 10. Mulher com a rodilha na cabeça e o cântaro assente sobre ela.

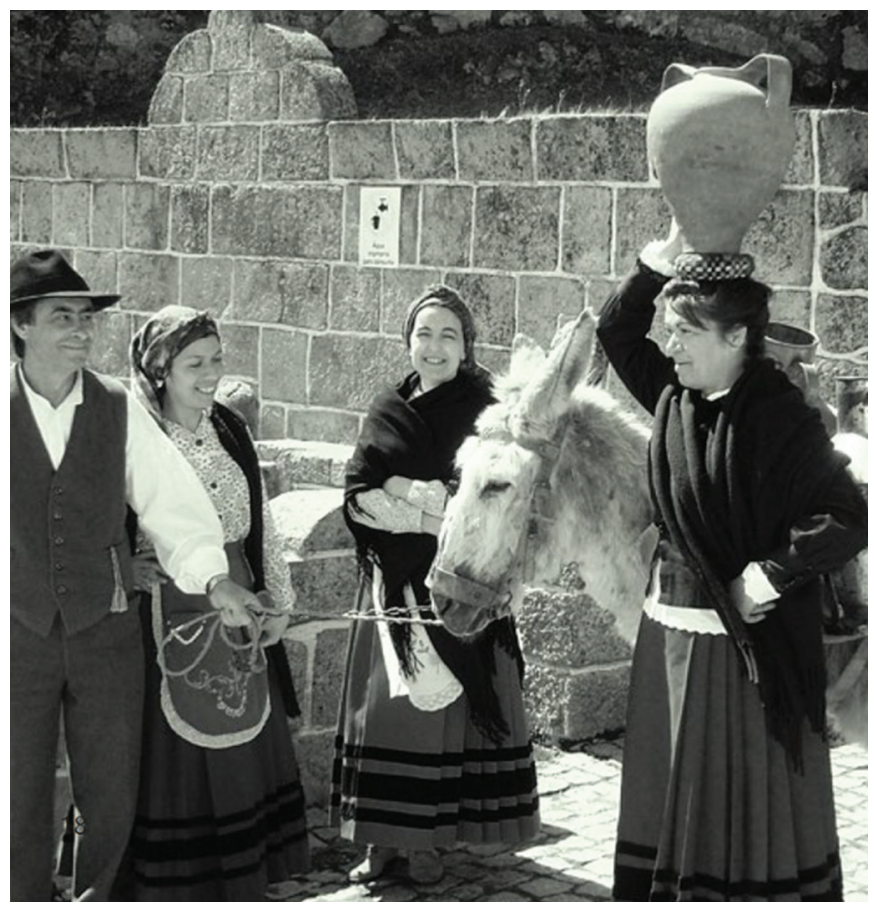

Fonte: Nabais, 2012, 189.

"No Couto o quê" - indaguei. "No Couto treinam todos os dias, pois não há água canalizada prás casas"

Em linhas gerais, este texto dá a conhecer um jogo tradicional, com origem laboral, relacionado com a água que, sendo uma manifestação de expressão popular constitui, também, um importante património cultural que é importante preservar. Um diálogo com as crianças poderá contribuir para a valorização da água e para fomentar o seu interesse na exploração do seu ciclo urbano. É possível, assim, discutir também as vantagens e desvantagens do progresso, clarificando que a ida à fonte buscar água, naquele tempo, era também uma forma de socialização e de bem-estar já que constituíam momentos partilhados, de conversa e de afetos entre as pessoas da comunidade. E tudo isto terá de ser, de novo, explorado de forma devidamente contextualizada e integrada com os saberes adquiridos nas atividades que terão sido previamente desenvolvidas.

Dar a conhecer às crianças os engenhos hidráulicos tradicionais, como picotas, moinhos de água, noras, azenhas, lagares mas também sistemas de rega tradicionais como levadas, poços artesanais, açudes, tapumes e represas, ainda presentes em muitas regiões portuguesas, assim como celebrações, festas e romarias cuja essência se enfoca na água, na sua importância para as atividades de consumo humano e animal e para a produção agrícola, podem constituir-se também como atividades muito pertinentes numa efetiva educação para a água.

De seguida, poder-se-á proceder à exploração de imagens ou de excertos de textos que ilustrem a forma como, ainda hoje, em muitas regiões do mundo, se tem de andar grandes distâncias para ir buscar a água necessária para a satisfação das necessidades básicas. O contraste com o que se passa nessas regiões, mais desfavorecidas (Figura 11), com o que ocorre em Portugal, que já tem implementado um sistema público de abastecimento de água, gerenciado de forma segura e cobrindo a quase totalidade do território, contribuirá para uma maior valorização e, consequentemente, para uma melhor compreensão e interiorização da necessária mudança de comportamentos e de atitudes relativamente à água, nomeadamente a respeito da necessidade de a poupar e de se preservar a sua qualidade numa perspetiva de cidadania e de contribuição para a sustentabilidade do planeta Terra.

É importante consciencializar as crianças de que as pessoas que não têm acesso a serviços de água potável seguros, são as que apresentam maiores níveis de pobreza. Poder-se-á dar como exemplo as zonas rurais muito carenciadas da África subsariana, onde as mulheres e as raparigas têm de percorrer grandes distâncias para ir buscar água, o que impede que tenham tempo disponível para estudar e ir à escola, ou mesmo para trabalharem noutras atividades. Como é referido no WWDR 2019, a falta de “água potável para consumo e higiene, bem como instalações sanitárias inadequadas, contribuem para o absentismo e altas taxas de abandono, principalmente entre as meninas" 51 . É importante discutir com as crianças o papel da educação. É preciso que elas compreendam que se essas populações menos favorecidas economicamente tivessem um melhor acesso à água a vida dessas crianças seria certamente diferente, e que a educação joga um papel fundamental na erradicação da pobreza.

É igualmente importante consciencializá-las que cerca de metade da população dessa região africana bebe água de fontes não protegidas, e que a falta de qualidade da água é responsável pelo aparecimento de muitas doenças, pondo em destaque a importância de se dispor de água potável segura.

De salientar que, no caso de crianças mais velhas ou de jovens, as atividades que integram a proposta apre-

\footnotetext{
50. Cabral, 2002, 8.
}

51. UNESCO, 2019, 30-31. 
Figura 11. Crianças vão buscar água durante um período de seca na Índia.

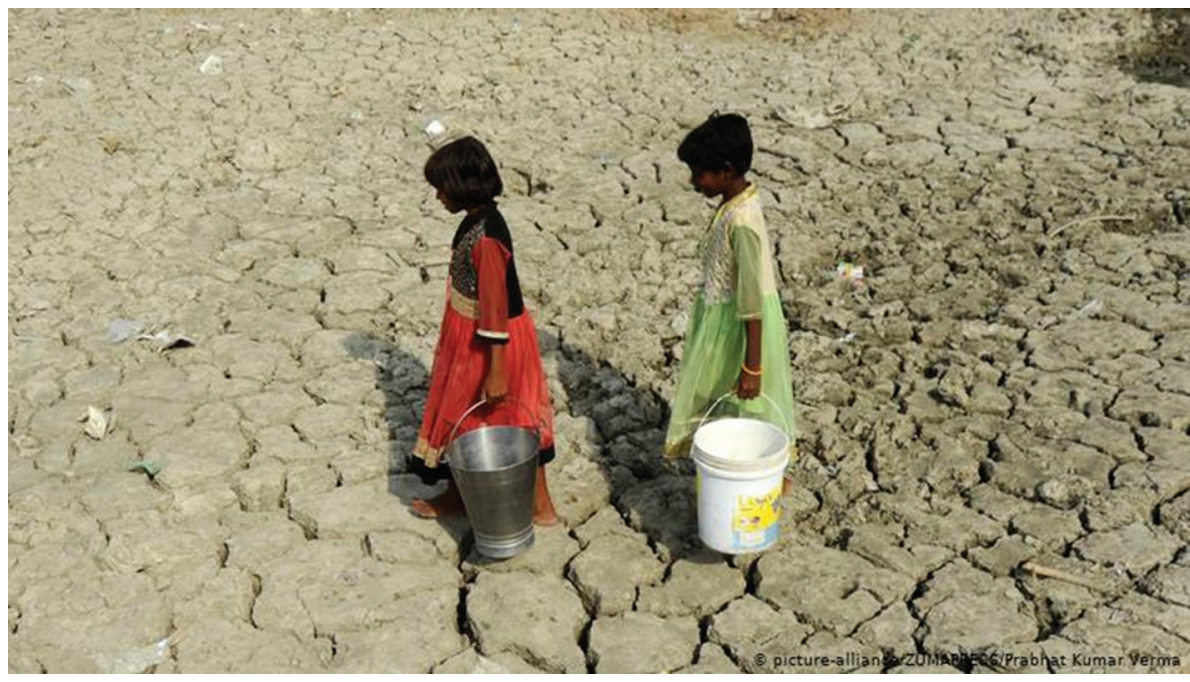

Fonte: https://www.dw.com/pt-br/pobres-pagam-mais-pela-\%C3\%A1gua-do-que-ricos-afirmaonu/a-47974940

sentada poderão ser igualmente desenvolvidas, mas, nesse caso, é fundamental adequar o grau de complexidade da atividade prática/experimental apresentada, das explicações científicas, da exploração dos aspetos culturais, sociais, ambientais e económicos. Por exemplo, na atividade em que se propõe explorar a analogia entre o que se passa nos recipientes de barro não vidrado e no nosso corpo quando transpiramos, poderá ser introduzido o conceito mais complexo de homeostasia, em particular do corpo humano. Ou, quando se explorar a desigualdade no acesso a água potável segura, explorar situações que mostrem essas diferenças não só entre regiões distintas do planeta, mas também dentro dos próprios países ou regiões. Poder-se-á também explorar quais os tipos de problemas principais com que se debatem as regiões áridas e semiáridas e discutir possíveis soluções de melhoria para os mesmos. Isto permitirá desenvolver conhecimentos e outros saberes, mas também fomentar atitudes e valores compatíveis com a promoção da sustentabilidade do planeta e a resolução de questões problemáticas direta ou indiretamente relacionadas com a escassez e a má qualidade da água.

\section{Considerações finais}

Educar para a água as novas gerações é um caminho a trilhar para se poder fazer frente à crise da água. É um trabalho árduo, difícil, mas estamos convictas de que uma conjugação de esforços concertada entre as instituições de educação formal e não formal pode ajudar a trilhar o caminho. Mas esse caminho faz-se andando, pelo que é necessário que essa educação se inicie desde cedo, permitindo às crianças desenvolver o gosto de aprender sobre a água e de aprender cada vez mais e melhor.

A proposta de atividades que se descreve neste artigo partiu da convicção de que para que as aprendizagens sejam mais efetivas e significativas as atividades em que se envolve as crianças devem ser social, económica, ambiental ou culturalmente contextualizadas. E como se defende que a preservação da nossa herança cultural é o pilar que deve ancorar o futuro, privilegiam-se como contexto de partida tradições portuguesas, enquanto parte importante da nossa história e da nossa cultura, que ao darem-se a conhecer permitem que fiquem registadas nas memórias das novas gerações. Estas tradições integram o património cultural imaterial, principal gerador da diversidade cultural e garante do desenvolvimento sustentável, que a Convenção para a Salvaguarda do Património Cultural Imaterial de 2003, no seu artigo 2.․, define como:

"as práticas, representações, expressões, conhecimentos e competências - bem como os instrumentos, objetos, artefactos e espaços culturais que lhes estão associados - que as comunidades, os grupos e, sendo o caso, os indivíduos reconheçam como fazendo parte integrante do seu património cultural. Esse património cultural imaterial, transmitido de geração em geração, é constantemente recriado pelas comunidades e grupos em função do seu meio envolvente, da sua interação com a natureza e da sua história, incutindo-lhes um sentimento de identidade 
e de continuidade, contribuindo, desse modo, para promover respeito pela diversidade cultural e pela criatividade humana. Para efeitos da presente Convenção, só será tomado em consideração o património cultural imaterial que seja compatível com os instrumentos internacionais relativos aos direitos humanos existentes, bem como com a exigência do respeito mútuo entre comunidades, grupos e indivíduos, e de um desenvolvimento sustentável"52.

Acreditamos que é fundamental levar as crianças a aperceberem-se da existência de uma relação muito estreita entre a educação e a cultura - no caso da proposta apresentada a educação para a água e a cultura sobre a água -, pois ambas procuram preservar práticas, expressões e representações que herdamos e que se manifestam em tradições e expressões orais, em práticas sociais, rituais e eventos festivos, em conhecimentos e práticas relacionadas com a natureza e o universo e em saberes e técnicas tradicionais que, por sua vez, estão associados a determinados saberes e técnicas e a objetos e lugares. Como Bohne refere “A memória é a sobrevivência do passado e a lembrança não é reviver, mas refazer, repensar, com imagens e ideias de hoje, as experiências do passado" 53 .

Poder-se-á perguntar: Todas as tradições têm uma explicação científica? Não, nem todas! Por exemplo, enquanto as crianças poderão facilmente verificar a veracidade do provérbio “Água detida é má para bebida" ${ }^{54}$ realizando uma atividade prática experimental, o mesmo não é possível para a expressão "Presunção e água benta: cada qual toma a que quer" 55 . Mas isto não significa que as tradições não tenham lugar no mundo atual, não lhes retira o seu valor, pois elas são o suporte sobre o qual se edificou a nossa sociedade.

Dado o seu interesse cultural, é preciso passar às gerações futuras o testemunho das nossas tradições e dos nossos saberes culturais sobre a água, pois só assim eles poderão ser valorizados e salvaguardados. Para isso, é necessária uma educação que reative esses saberes e os saberes-fazer comunitários, despertando nas crianças a consciência de quão importante é a sua preservação na projeção do futuro. Quão importante é saber, por exemplo, manter a água fresca sem necessitarmos de consumir eletricidade ou a importância das relações sociais, do convívio saudável em torno da utilização comunitária dos equipamentos ligados à recolha e ao transporte da água. É importante transmitir às novas gerações tradições e sa-

\footnotetext{
52. UNESCO, 2003, 3-4.

53. Bohne, 2016, 9.

54. Ferreira, 1999.

55. Ferreira, 1999.
}

beres ligados à água, ao seu aproveitamento e bom uso. É preciso desenvolver atitudes e valores que defendam a água e a implementação de medidas tendo em vista a promoção da sustentabilidade do planeta e o bem-estar da população. A sustentabilidade do planeta depende de uma sociedade bem informada cientificamente, neste caso dominando conhecimentos científicos sobre a água (composição química, propriedades da água e a sua importância para os seres vivos, qualidade da água, ...) mas também bem formada em termos de valores como a preservação dos saberes ancestrais, a partilha, a valorização do planeta e, por fim, que atue em conformidade com esses conhecimentos e esses valores.

É preciso, também, que os educadores/professores reflitam sobre as implicações do que e do como aprender sobre a água que ajudam a pensar na relação que deve existir entre educação para a água e cultura da água. É imprescindível que reflitam sobre a forma de incorporar esses saberes ancestrais e tradições no desenvolvimento dos objetivos curriculares e nas suas implicações no meio ambiente tendo em conta a sustentabilidade do planeta. Só assim poderão contribuir para a preservação da memória coletiva e para a valorização da nossa identidade rumo a um futuro sustentável.

Porém, só educadores/professores científica e pedagogicamente bem preparados e alertados para a complementaridade dos diversos contextos de aprendizagem formal e não formal e, também, informal poderão explorar todo o potencial da relação entre estes contextos para que as crianças aprendam a... e sejam educadas a... utilizar de forma adequada a água com base nos ensinamentos e nas práticas dos nossos antepassados de forma a ajudar a garantir a sustentabilidade do planeta.

\section{REFERÊNCIAS BIBLIOGRÁFICAS}

Bohne, L. S. M. 2016: "Los espacios cotidianos del uso del agua en Guadalajara, 1892-1960". Diversae. Revista del Seminario de Historia Mexicana, 2 (2), 9-33.

Bonafé, J. 2011: Políticas do manual escolar. Mangualde (Portugal), Pedagogo.

Cabaço, L. (Coord.) 2017: Relatório nacional sobre a implementação da Agenda 2030 para o Desenvolvimento Sustentável. Portugal. Lisboa (Portugal), Ministério dos Negócios Estrangeiros.

Cabral, A. 2002: 0 Mundo fascinante do Jogo. Lisboa (Portugal): Notícias.

Carvalho, A. B. 2015: A história das ciências na abordagem do tema evolucionismo dos manuais escolares de Biologia do $71 .{ }^{\circ}$ ano de escolaridade: recursos mobilizados, imagens de ciência e de cien- 
tista veiculadas e perceção dos professores, tese de mestrado, Universidade do Minho, Braga (Portugal).

Castilho, J. 1968: "Pregões de Lisboa, Música do Coração do Povo". Revista Municipal de Lisboa, 73, 116-117.

Chaves, E. 2004: Conceito de educação: a filosofia da educação e a análise de conceitos educacionais. http://www. educadores. diaadia.pr.gov.br/arquivos/File/2010/artigos_teses/filosofia_da_ educacao.pdf. Consulta realizada em 20 de fevereiro de 2019.

Coelho, A. C. P. 2018: "Aú, água fresca, água fresquinha: uma análise humanística sobre a figura dos galegos aguadeiros em Lisboa". Madrygal. Revista de Estudios Gallegos, 20, 189-204.

Comissão da Cultura - Cidades e Governos Locais Unidos 2015 Culture 21: Agenda 21 da Cultura. Barcelona (Espanha), CGLU.

Duarte, C. Z. C. G.; Werneck, V. R. e Cardoso, J. A. R. 2013: "A relação entre cultura e educação sob o ponto de vista de educadores do ensino fundamental". Psicologia e Saber Social, 2 (2), 204-216. https://doi.org/10.12957/psi.saber.soc.2013.8794

Erich, A. 2018: "The role of public libraries in non-formal learning". Romanian Journal for Multidimensional Education, 10 (3), 17-24. https://doi.org/10.18662/rrem/59

Ferreira, J. A. 1999: Literatura Popular de Trás-os-Montes e Alto Douro. Vila Real (Portugal), Minerva Transmontana.

FFMS (Fundação Francisco Manuel dos Santos) (Ed.) 2019a: População servida por sistemas públicos de abastecimento de água, sistemas de drenagem de águas residuais e estações de tratamento de águas residuais (ETAR) (\%). http://www.pordata.pt. Consulta realizada em 15 de fevereiro de 2020.

FFMS (Fundação Francisco Manuel dos Santos) (Ed.) 2019b: Qualidade da água para consumo humano. PORDATA - Água Segura. http:// www.pordata.pt. Consulta realizada em 15 de fevereiro de 2020.

Figueiroa, A. M. 2003: "Uma análise das atividades laboratoriais incluídas em manuais escolares de Ciências da Natureza (5. ${ }^{\circ}$ Ano) e das conceções dos seus autores". Revista Portuguesa da Educação, 16 (1), 193-230.

Freire, P. 1987: Pedagogia do Oprimido. Rio de Janeiro (Brasil), Paz e Terra.

Froehlich, C. 2014: "Sustentabilidade: dimensões e métodos de mensuração de resultados". Desenvolve. Revista de Gestão do Unilasalle, 3 (2), 151-168.

Gama, E. 1954: Os pregões de Elvas. Lisboa (Portugal), Álvaro Pinto.

Gaspar, A. 1993: Museus e centros de ciências - Conceituação e proposta de um referencial teórico, tese de doutoramento, Universidade de São Paulo, São Paulo (Brasil).

Guimarães, F. 2009: "A Importância de ser professor no 1. ${ }^{\circ}$ Ciclo: Conhecimento escolar e manuais escolares", Atas das II Jornadas de Educação. Braga (Portugal), Universidade do Minho.

INE (Instituto Nacional de Estatística) (Ed.) 2019: Objetivos de Desenvolvimento Sustentável - Indicadores para Portugal - Agenda 2030. Lisboa (Portugal), INE.
Langhi, R. e Nardi, R. 2009: "Ensino da astronomia no Brasil: educação formal, informal, não formal e divulgação científica". Revista Brasileira de Ensino de Física, 31 (4), 4402-4411. https://doi. org/10.1590/S1806-11172009000400014

Marandino, M. (Org.) 2008: Educação em museus: a mediação em foco. São Paulo (Brasil), Universidade de São Paulo.

Marandino, M. 2017: "Faz sentido ainda propor a separação entre os termos educação formal, não formal e informal?". Ciência \& Educação, 23 (4), 811-816. https://doi.org/10.1590/1516731320170030001

Marques, J. B. V. e Freitas, D. 2017: "Fatores de caracterização da educação não formal: uma revisão da literatura". Educação e Pesquisa, 43 (4), 1087-1110. https://doi.org/10.18675/19818106.vol28.n58.p241-261

Marques, J. B. V. e Freitas, D. 2018: "Evolução da pesquisa em educação não-formal e divulgação científica no Brasil: um meta-estudo". Educação: Teoria e Prática, 28 (58), 241-261.

Martins, D. 2011: Os manuais de Estudo do Meio e o ensino experimental das ciências no $1 .^{\circ}$ ciclo do ensino básico, tese de mestrado, Instituto Politécnico de Bragança, Bragança (Portugal).

Martins, R. N. e Nunes, F. 2016: "A sustentabilidade cultural no âmbito das políticas de desenvolvimento sustentável da União europeia: o papel da cultura nas distinções da Capital Verde Europeia", em Pina, H.; Remoaldo, P. \& Ramos, C. (Orgs.), The Overarching Issues of the European Space: Rethinking Socioeconomic and Environmental Problems. Porto (Portugal), Faculdade de letras da Universidade do Porto, 252-263.

Matos, H. 2012: 0 vasilhame de barro de Estremoz. https://dotempodaoutrasenhora.blogspot.pt/search?q=C\%C3\%A2ntaros+de+\%C3\%81 gua. Consulta realizada em 7 de março de 2018.

Morhy, P. E. D.; Terán, A. F. e Fonseca, A. P. 2019: “0 tema água em espaços não formais: possibilidades de aprendizagem em ciências", em Batista, N. L.; Feltrin, T. e Rizzatti, M. (Orgs.). Formação, Prática e Pesquisa em Educação 2. Ponta Grossa (Brasil), Atena Editora, 191-199. https://doi.org/10.22533/at.ed.91419030918

Nabais, J. 2012: Objectos que contam.... Penamacor (Portugal), Museu Municipal.

Oliveira, R. I. e Gastal, M. L. 2009: "Educação formal fora da sala de aula: olhares sobre o ensino de ciências utilizando espaços não formais", em Mortimer, E. (Org.), Atas do VII Encontro Nacional de Pesquisa em Educação em Ciências. Florianópolis (Brasil), Associação Brasileira de Pesquisa em Educação em Ciências, 1-11.

0 Mirante 2018: Falta de água é o principal problema do rio Tejo. https://omirante.pt/semanario/2018-01-18/economia/ 2018-01-17-Falta-de-agua-e-o-principal-problema-do-rio-Tejo. Consulta realizada em 25 de janeiro de 2020.

ONU (Organização das Nações Unidas) 2000: Objetivos do Milênio. http://www.objetivosdomilenio.org.br/. Consulta realizada em 7 de janeiro de 2019. 
Péres, P.; Tomás, H. M. e Afonso, M. 2015: 0 barro e a olaria - Na ciência e na tradição. Um livro para educadores. Castelo Branco (Portugal), Instituto Politécnico de Castelo Branco.

PNUD (Programa das Nações Unidas para o Desenvolvimento) 2006: Relatório do Desenvolvimento Humano - A água para lá da escassez: poder, pobreza e a crise mundial da água. Nova lorque (Estados Unidos da América), PNUD.

Rogers, A. 2004: Looking again at non-formal and informal education - Towards a new paradigm. http://www.infed.org/biblio/ non_formal_paradigm.htm. Consulta realizada em 20 de março de 2020.

Rogers, A. 2014: The base of the iceberg: Informal learning and its impact on formal and non-formal learning. Berlin (Alemanha), Barbara Budrich Publishers. https://doi.org/10.3224/84740632

Sánchez-Rodríguez, M. 2017: "Del barro al tereftalato de polietileno: el oficio de aguador en México". Agua y Territorio, 9, 22-33. https://doi.org/10.17561/at.v0i9.3474

Santos, W. L. P. D. 2007: "Educação científica na perspectiva de letramento como prática social: funções, princípios e desafios". Revista Brasileira de Educação, 12 (36), 474-492. https://doi. org/10.1590/S1413-24782007000300007

Serra, C. 2012: Da problemática ambiental à mudança. Rumo a um mundo melhor. Maputo (Moçambique), Escolar Editora.

Silva, E. R. 1998: 0 curso da água na história: Simbologia, Moralidade e a gestão de recursos hídricos, tese de doutoramento, Fundação Oswaldo Cruz, Rio de Janeiro (Brasil).

UN (United Nations) 2010a: Human rights and access to safe drinking water and sanitation: resolution / adopted by the Human
Rights Council. UN Doc. A/HRC/RES/15/9, 30 September 2010. https://www.right-docs.org/doc/a-hrc-res-15-9/. Consulta realizada em 23 de novembro de 2017.

UN (United Nations) 2010b: The human right to water and sanitation: resolution / adopted by the General Assembly. UN Doc.A/ RES/64/292, 28 July 2010. https://www.refworld.org/docid/4cc926b02.html. Consulta realizada em 23 de novembro de 2017.

UN (United Nations) 2015: Transforming our world: The 2030 agenda for sustainable development. Nova lorque (Estados Unidos da América), ONU.

UNESCO (Organização das Nações Unidas para a Educação, a Ciência e a Cultura) 2002: Declaração universal sobre a diversidade cultural. Paris (França), UNESCO.

UNESCO (Organização das Nações Unidas para a Educação, a Ciência e a Cultura) 2003: Convenção para a salvaguarda do património cultural imaterial. Paris (França), UNESCO.

UNESCO (United Nations Educational, Scientific and Cultural Organization) 2019: The United Nations world water development report 2019: leaving no one behind. Paris (França), UNESCO.

WHO (World Health Organization) 2011: Guidelines for drinking-water quality. 4.ed. Geneve (Suiça), World Health Organization.

WWF-Brasil (World Wide Fund for Nature-Brasil) (Coord.) 2007a: Cadernos de Educação Ambiental - Guia de atividades. Brasília (Brasil), WWF. www.wwf.org.br. Consulta realizada em 6 de março de 2018.

WWF-Brasil (World Wide Fund for Nature-Brasil) (Coord.) 2007b: Cadernos de Educação Ambiental - Livro das Águas. Brasilia, WWF. www.wwf.org.br. Consulta realizada em 6 de março de 2018. 